\title{
Demographic Challenges to Sustainability of Small Adriatic Islands: the Case Study of Ilovik, Croatia
}

\section{Ivan $\check{S} u l c$}

University of Zagreb, Faculty of Science, Department of Geography, Croatia e-mail: isulc@geog.pmf.hr

\section{Mila Zlatić \\ University of Maryland, Department of Geographical Sciences, Maryland, USA}

e-mail:mila.zlatic@umd.edu

\begin{abstract}
The traditional way of life on small islands throughout the word is in danger. This paper, a case study of Ilovik, one particular small island in the Adriatic Sea, examines how negative demographic trends impact socio-economic and environmental processes and present special challenges to planning and implementing sustainable development. The primary research was conducted by collecting survey responses from the island's residents for two weeks in mid-June of 2011 on their current socioeconomic status, the natural environment, the residents' and vacation home owners' perception of tourism, the government's impact on socio-economic change, and the perception of the influence of the EU on future development. The results were analyzed and compared with the official data from government sources (censuses and live statistics). The analysis was performed with the central goal of examining the current sustainability of Ilovik and providing an understanding of its future fragile development perspectives which would depend on the population recovery and further increase of employment opportunities, always bearing in mind the delicate ecosystem and the unique cultural heritage of the small island.
\end{abstract}

Key words: depopulation, sustainable development, small islands, Ilovik, Adriatic islands, Croatia. 


\section{Introduction}

Negative demographic trends on the Adriatic islands predominantly caused by economic factors have had serious impacts on their socio-economic and environmental processes. These processes are even more amplified on small remote Adriatic islands. With the present population trends and economic capacity, do these islands have any opportunity for sustainable development in the future? The definition of the term sustainable development has been attributed to the report of the World Commission on Environment and Development (WCED): Our Common Future, whose main goal is to recognize "development that meets the needs of the present without compromising the ability of future generations to meet their own needs" (WCED, 1987).

Because small islands' development options are limited, they present special challenges to planning and implementing sustainable development (Bayle-Ottenheim et al., 2001). Sustainable development theorists posit that global sustainability can be attained through small "islands" (contained local communities), because such communities deal with issues of resource management and carrying capacity at a smaller scale (Deschenes and Chertow, 2004). Therefore, an isolated island community could provide a model for responsible economic development (Mackelworth and Carić, 2010).

The aim of this paper is to provide an insight into the sustainable development of a small Croatian island, Ilovik, situated at the far end of the Kvarner archipelago, near the island of Lošinj (in the northern Adriatic Sea). Neglected due to its small size, lack of resources, reduced manpower, and relative inaccessibility, Ilovik faced considerable vulnerability and sustainability challenges. For decades the island did not have daily connection to county or regional centers. Only recently a regular daily boat line is linking the island with the country center, Mali Lošinj. Ilovik has a surface area of 4.6 square kilometers (Duplančić Leder, Ujević and Čala, 2004) (Figure 1), only one settlement with 85 permanent residents in June 2011 (University of Maryland [UMD], 2011a), and about 180 building structures. It is quite literally an island community, and exploring the possibilities for sustainable development on Ilovik has weight in the larger discourse of sustainability. Presently, Ilovik is facing many of the issues other small islands, as well as Croatia itself faces: depopulation, an aging population, and an unhealthy economy (Faričić, Graovac and Čuka, 2010; Lajić, 2005; Lončar and Maradin, 2009; Starc, 2001; Šulc and Valjak, 2012). While in the past Ilovik was self-sustaining through agriculture and fishing, its current economy depends primarily on tourism. It has been universally accepted that tourism is a vital factor in the development of remote and small communities by enabling their transition from agriculture-based to service economies (Buhalis, 1999; Magaš, Brkić Vejmelkaand, Faričić, 2000; Faričić and Mikuličić, 2010; Magaš, 2008). But, it has also raised questions about whether rapid development stands in the way of the prosperity of local people as well as the sustainability of local resources (Nunkoo, Gursoy and Juwaheer, 2010). 
Figure 1

Geographic situation of Ilovik in the northern Adriatic Sea

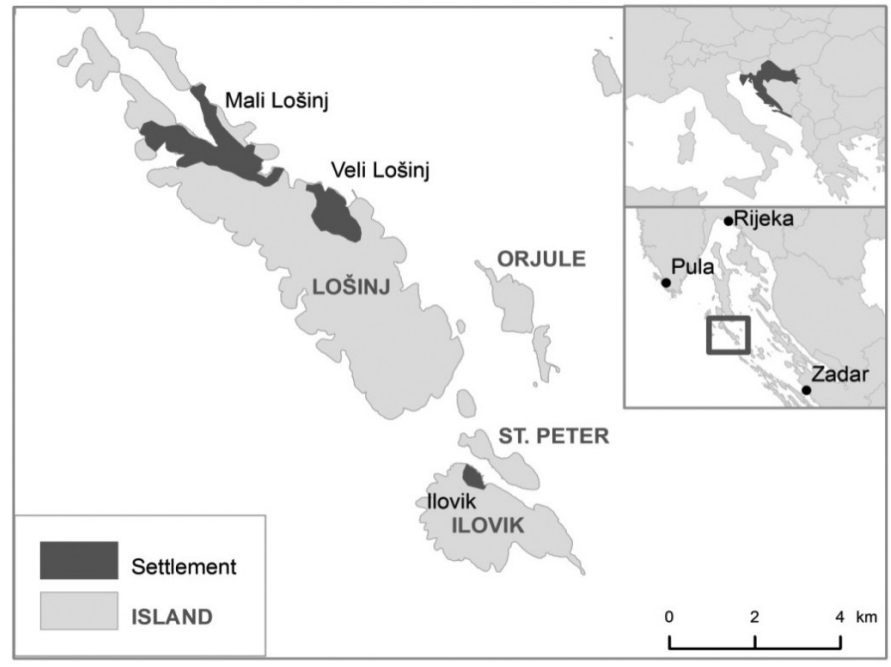

Source: State Geodetic Administration [SGA] (2005) (modified)

This paper will describe and illustrate the state of the current population, this small isolated island's economy and tourism, the effectiveness of government, and the possible impact of the accession to the European Union (EU) on the island's development. The goal of this paper is to determine the sustainability of Ilovik's future development by taking into consideration past and current rates of depopulation and socio-economic transformation, the residents' perception of the government's impact on socio-economic change, as well as the perception of the influence of the EU on future development. Although the main conclusions for the population analysis were drawn from the data collected and/or the interviewed permanent residents, the other interviewees (dual citizens and vacation homeowners) perceptions on future course of development were presented as they have significant influence on the prospects of Ilovik.

\section{Methodology}

Ilovik's remote location, away from the county center Mali Lošinj, or regional center Rijeka, and long lasting limited connections to the rest of the region added to its economic and demographic decline making it especially interesting as a case study for sustainability development of a truly isolated community. In June 2011, a research team, five members from the Department of Geographical Sciences, University of Maryland and one member from the Department of Geography, Faculty of Science, University of Zagreb, conducted an extensive interview for nearly the entire population present during the research period. The interviews were conducted in Croatian and/or English as many interviewees spoke English fluently. Besides, two interviews were conducted in Italian. The survey covered the demographics, socio-economic, and environmental conditions on Ilovik, and present use of all building structures 
in order to determine past development, present condition, and future prospects of the island. The interviewees were divided into three groups: (1) permanent residents (have their residency on Ilovik and live on the island year-round, including longterm renters), (2) dual residents (have permanent residency in another place, but live at least 6 months per year on Ilovik), and (3) vacation home owners (live off of the island and spend their vacation on Ilovik). Fifty seven heads of households were interviewed, representing almost all permanent residents, including home owners and long term renters. Dual residents and vacation home owners who were residing on the island at the time of the survey were also interviewed. The structured interviews included general information about the respondents and members of their households, their socio-economic status, property ownership and land use changes, tourism, interviewees' perception of the environment, their view on the effects of the accession of Croatia to the EU, and the government's role in the development of the island. Local business owners were also interviewed using a modified version of the survey.

We analyzed population data obtained from the survey about permanent residents, but not dual residents and vacation home owners. The information includes: age characteristics, sex composition, educational attainment, economic structure, and size of the household. The population ageing was evaluated by using a classification of population according to the share of young (0-19) and elderly (60 and above) in the total population (Nejašmić, 1992:28; Nejašmić and Mišetić, 2006:305; modified according to Klemenčić, 1990:77-78) ${ }^{1}$. Educational attainment includes only population older than 15 years, and is expressed by educational index based on finished level of education of this segment of population $\left(\mathrm{I}_{\mathrm{E}}=\left(\mathrm{E}_{\mathrm{II}} \times \mathrm{E}_{\mathrm{III}}\right) /<\mathrm{E}_{\mathrm{I}}\right)$ (modified according to: Nejašmić, 2005:203). Besides analyzing the survey results in 2011, we investigated population processes using census data from 1857 to 2001 and vital statistics (live births and deaths) and net-migration from 1961 to 2011, thus enabling projections for future population development on the island.

In addition to the general population and household analysis, we explored the state of economic development on Ilovik. Data on private businesses and their employees was collected from the modified version of the interview, providing non-residential socio-economic data to complete the village's dataset. Owners of all private businesses on the island were interviewed, and the information about employment in the public sector was obtained by the employees. The data was sorted by the sector of activity (primary or tertiary), the ownership (public and private), type of

1 According to Nejašmić modified model, there are seven classes (types) of ageing according to the points assigned to the share of young (0-19) and elderly population (60 and above) in the total population. The share of young population is scored from 0.0 to 30.0 points (the higher share of the young population is the higher score) and the share of elderly population from 0.0 to 70.0 (the higher share, the lower score). Eventually, the scores assigned to both groups are counted. Lower score refers to aged population and higher score to less aged population. According to the total score seven classes (groups) of ageing are formed: (1) the threshold of ageing, (2) ageing population, (3) aged population, (4) old population, (5) very old population, (6) extremely old population and (7) ultimately old population. 
employment (full or part time), and the place of residency (permanent residency on the island or migrants).

The survey conducted in June 2011 included a section on the perception of the island's population on the government's impact on economic development, as well as their perception of the EU's influence on future development. The results of the above topics were included in the analysis to reinforce the major purpose of this study: to assess sustainability of future development on Ilovik.

\section{Data analysis}

In June 2011, data was collected through an extensive survey of 57 households and all 10 business owners on the island. Of all the interviewed households, 30 were permanently residing on Ilovik. The other interviewees were either dual citizens (four households) or vacation home owners (24 homeowners). Most permanent residents' households owned the house they lived in; three were long term renters.

In this population analysis the survey results have been compared with the historic data from government sources (censuses and live statistics) only for the permanent residents, because they have a significant impact on the overall socioeconomic and environmental development of the island. Although other homeowners (vacationers or dual citizens) who own more than 50 percent of housing units impact development of the island, their contribution in population development is beyond the scope of this paper. Their views will be included in the analysis of the research only in respect to future development of the island 2011.

\subsection{Population dynamics}

At the time of the survey, there were a total of 37 permanent residents' households with a total of $85^{2}$ residents on Ilovik; of those 7 households were not interviewed ( 6 one-member households and one two-member household). The 30 permanent resident households interviewed represented over $90 \%$ of the total population. Fifteen households were one-person households, 14 were two-person households, and only eight had three and more members. Compared with 1961, there were three times fewer permanent resident households on the island in 2011. One and two-person households have doubled their share in the number of all households, three-person households have been cut in half, four-person households have been reduced to one fifth, and households with five and more members were reduced to one third of their share since 1961 (Table 1).

2 In Census on 31 March 2011 recorded the same number of people, but with slightly different age-sex composition (Croatian Bureau of Statistics [CBS], 2012). 
Table 1

Composition of the households on Ilovik by size in 1961 and 2011

\begin{tabular}{|c|c|c|c|c|}
\hline \multirow{2}{*}{$\begin{array}{c}\text { Members in the } \\
\text { household }\end{array}$} & \multicolumn{2}{|c|}{$\mathbf{1 9 6 1}$} & \multicolumn{2}{c|}{$\mathbf{2 0 1 1}$} \\
\cline { 2 - 5 } & $\begin{array}{c}\text { Number of } \\
\text { households }\end{array}$ & Share (\%) & $\begin{array}{c}\text { Number of } \\
\text { households }\end{array}$ & Share (\%) \\
\hline One & 21 & 20,2 & 15 & 40.5 \\
\hline Two & 19 & 18,3 & 14 & 37.9 \\
\hline Three & 17 & 16,3 & 3 & 8.1 \\
\hline Four & 15 & 14,4 & 1 & 2.7 \\
\hline Five or more & 32 & 30,8 & 4 & 10.8 \\
\hline Total & 104 & 100,0 & 37 & 100,0 \\
\hline
\end{tabular}

Sources: Savezni zavod za statistiku [SZS] (1965d); UMD (2011a)

Demographic development of Ilovik can be divided into three main periods: First, population growth from 1857 to 1921 characterized by steady growth ${ }^{3}$. The population grew by 33\% (from 385 to 512 people) from 1857 to 1921; second, moderate depopulation 1921-1961 and third, extreme depopulation 1961-present. In the first period, similar population growth was observed on almost all Kvarner islands, with the exception of Vele Srakane and Male Srakane (Lajić, 2006). In the period 19211961 the decline of the population of Ilovik was more severe than on the Croatian island (in total), Kvarner islands and Susak, but less severe than on Unije (Magaš, Faričić and Lončarić, 2006:211). After moderate depopulation at the beginning of the period 1961-2011, Kvarner and Croatian islands have recorded mild increase. On the other hand, depopulation of Ilovik was accelerated but it has been less intensive than on Unije and Susak. Therefore, the current small number of inhabitants on Ilovik is a result of enduring depopulation since 1921 (Figure 2).

Figure 2

Index of total population change on Ilovik, Susak, Unije, Kvarner islands and Croatian islands 1857-2011*

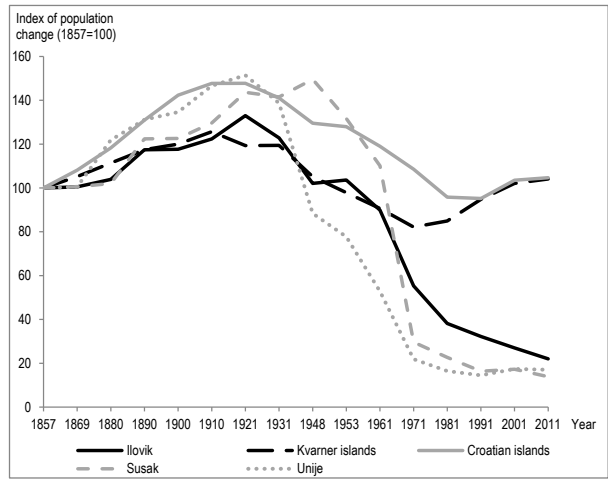

Sources: CBS (1996.); CBS (2005.); CBS (2012.);UMD (2012a)

*In 1991, only the contingent Population in the country was analyzed.

3 The island was populated in the late $18^{\text {th }}$ century when several inhabitants permanently moved from Veli Lošinj. They were engaged in agriculture and fishing (Magaš, Faričić and Lončarić, 2005.).Still, population data before the first population census (in 1857) was irregular and questionable, hence only the period since 1857 has been analyzed. 
The intensity of depopulation was the highest in the census period 1961-1971 (average annual rate of population change of -3.8 percent), followed by the period 19711981 ( -3.1 percent). The last three census periods have been characterized by lower, but still negative rates: in 1981-1991 (-1.8 percent), 1991-2001 (-1.6 percent), 20112011 (-1.8 percent). During this whole period of negative population change, more than half (52.1 percent) refers to the negative net-migration, and 47.9 percent to the negative natural change (natural fall). The net-migration was the highest in the period 1961-1971 (-108), followed by the period 1971-1981 (-38). From 1981 to 2001 the net-migration was low but positive, and in the last decade (2001-2011) the number of newcomers was equal to the number of people that left the island (Table 2).

Table 2

Total population change, natural change and net-migration on Ilovik 1961-2011 (by census periods)*

\begin{tabular}{|c|c|c|c|c|c|}
\hline Period & Live births & Deaths & $\begin{array}{c}\text { Natural } \\
\text { change }\end{array}$ & $\begin{array}{c}\text { Net- } \\
\text { migration }\end{array}$ & $\begin{array}{c}\text { Net- } \\
\text { migration }\end{array}$ \\
\hline $1961-1971$ & 13 & 38 & -25 & -108 & -133 \\
\hline $1971-1981$ & 15 & 43 & -28 & -38 & -66 \\
\hline $1981-1991$ & 5 & 35 & -30 & 7 & -23 \\
\hline $1991-2001$ & 7 & 30 & -23 & 3 & -20 \\
\hline $2001-2011$ & 10 & 29 & -19 & 0 & -19 \\
\hline $1961-2011$ & 50 & 175 & -125 & -136 & -261 \\
\hline
\end{tabular}

* Net-migration has been calculated as the difference between total population change and natural change. Source: CBS (2010.); UMD (2011a)

The number of live births during the past decades was very low (5-10 per decade), with the exception of the last decade (2001-2011) when the number of life birth was higher than 10 per decade, rather unusual for Ilovik ${ }^{4}$.

The absolute number of deaths on the island had been increasing slowly until the period 1981-1991 when it reached its peak of 30 deaths in ten years. During the last two decades a mild decrease was recorded. On the other hand, death rates have steadily increased: 13.6 deaths per thousand people in 1966: 28.9 in 1976, 28.0 in 1986; 31.6 in 1996; 21.1 in 2006 (calculated according to CBS, 2005; 2010; 2012).

There was a slight imbalance between sexes - 44 inhabitants were male and 41 were women (sex-ratio is 107.3) (Table 3). While women prevailed in elderly population (sex-ratio 80.0), men were predominant in the working age group (sex-ratio 128.6).

\footnotetext{
4 Birth and death rates have been calculated as average number of live births and deaths in the period from one year before the observed year to one year after the observed year and divided by the estimated population in the middle of the census period. The number of live births amounted to 6.4 pro mille in 1966; 5.6 in 1976; 4.4 in 1986; 3.5 in 1996; 10.6 in 2006 (calculated according to: CBS, 2005; 2010; 2012). Birth rate in 2006 is result of 3 live births in three years (2006-2008), resulted in higher than 10 birth in a decade.
} 
Present imbalance among younger adults (sex-ratio 150.0) is especially worrisome for continues bio-reproduction on the island.

In 2011, the median age for permanent residents on Ilovik was 58 years, 15 years higher than in Croatia; the male population being older than females (calculated according to CBS, 2012). Of the total population 11.7 percent were young $(0-14)$, 56.5 percent are of working age $(15-64)$ and 31.8 percent were elderly $(65$ and older). The share of elderly was 2.7 times higher than the share of young people placing the population of Ilovik among ageing populations according to all classifications (UN, 1956:7 cited in: Wertheimer-Baletić, 1982:248; Nejašmić, 2005:182). Among the working age population, older adults numerically dominated (28 persons or 58.3 percent), while younger adults had a share of 41.7 percent (20 persons). The age index was 270.0 and the old age dependency index was 56.3 (Table 3). According to the classification of ageing, Ilovik belongs to the sixth (penultimate) class of ageing: "extremely old population"'.

Besides the proportion of the working age population, educational composition is one of the key factors of socio-economic development. There were 75 permanent residents older than 15 years on the island in 2011. Seven had not finished eight years of primary education $\left(<\mathrm{E}_{\mathrm{I}}\right), 21$ had completed primary school $\left(\mathrm{E}_{\mathrm{I}}\right), 22$ had graduated from high school $\left(\mathrm{E}_{\mathrm{II}}\right), 8$ had two or more years of college education $\left(\mathrm{E}_{\mathrm{III}}\right)$, and 17 did not answer the question. Interestingly, among the best educated group, four were elderly (65 and above), two in the 25-44 age group, and two in the age group 45-64. Those with unfinished primary education were elderly, with the exception of those with documented learning disabilities in other age groups.

Table 3

Age-sex composition of the population of Ilovik in 2011

\begin{tabular}{|l|c|c|c|c|c|c|}
\hline \multirow{2}{*}{\multicolumn{1}{|c|}{ Age group }} & \multicolumn{3}{c|}{1961} & \multicolumn{3}{c|}{2011} \\
\cline { 2 - 7 } & M & F & Total & M & F & Total \\
\hline Young (0-14 y.) & - & - & 105 & $\mathbf{5}$ & $\mathbf{5}$ & $\mathbf{1 0}$ \\
\hline Younger adults (15-44) & - & - & 101 & 12 & 8 & 20 \\
\hline Older adults (45-64) & - & - & 80 & 15 & 13 & 28 \\
\hline Adults (15-64) & - & - & 181 & $\mathbf{2 7}$ & $\mathbf{2 1}$ & $\mathbf{4 8}$ \\
\hline Elderly (65 and above) & - & - & 60 & $\mathbf{1 2}$ & $\mathbf{1 5}$ & $\mathbf{2 7}$ \\
\hline Total & 144 & 202 & 346 & $\mathbf{4 4}$ & $\mathbf{4 1}$ & $\mathbf{8 5}$ \\
\hline
\end{tabular}

Source: SZS (1965.b); UMD (2011a)

$\mathbf{5}$ Final result represents a sum of 12.0 points assigned to the share of the young population in age $0-19$ (11.8 percent) and 27.0 percent assigned to the share of elderly population in age 60 and above ( 43.5 percent). 
In 1961, the age composition was more favorable; 30.4 percent of the population was young, 52.3 percent was of working age, and 17.3 percent were elderly. Still, the share of elderly was rather high. The younger, working age group outnumbered the elderly with 55.8 percent of the population. The old age dependency coefficient was 33.1. Because of the higher share of elderly, the population of Ilovik belonged to the third class of ageing ("aged population") with total of 78 points. The educational level of the population of Ilovik has improved significantly in the last 50 years. In 1961, 13.4 percent of population older than 15 years did not have primary education, 84.9 percent had primary education, and only 1.7 percent had secondary education. No one on the island had any higher education (SZS, 1965c). In 2011, the educational index of the Ilovik's population was 43.3, significantly higher than the Croatian average in 2001 (30.4) (CBS, 2003), and the trend continued through that decade. ${ }^{6}$

\subsection{Economic attainment}

The economic development of Ilovik is intertwined with the population characteristic on the island. As Ilovik's economic dynamics havebeen greatly influenced by the population changes, the present economic composition of permanent residents on Ilovik is compared to the situation in 1961, when intensive deagrarization began, pushing people to leave the island and causing economic restructuring.

We analyzed the employment structure to determine if the present population structure could sustain economic development. At the time of the survey there were more than 60 people employed on the island (23 full time, three part time and 39 seasonally). A slight majority (34) of those employed was permanent residents (including seasonally employed and half-time employees), one permanent resident among the active population group was unemployed, and one was on maternity leave. 31 permanent residents had a personal (retirement) income and 18 were dependent (children, disabled, and housewives). In 1961, the population of the island was almost four times larger. About 30 percent were active and all were permanent residents, 7 percent had personal income, and 63percent were dependent, mostly children (SZS, 1965a).

In 2011, two thirds of permanent residents were employed in services, four in construction (one full time, and three seasonally), three worked in agriculture, and four were fishermen. Several households still tended a few sheep, most grew their vegetable gardens, and 16 households fished for their own needs. This was in sharp contrast to half a century earlier, when just over ten percent were employed in services (public) and almost 90 percent in agriculture, tending sheep, vineyards and olive gardens, and fishing (Table 4).

6 Data for the Census 2011 on education is not yet available. 
Table 4

Composition of the working population on Ilovik by the sector of activity in 1961 and 2011

\begin{tabular}{|c|c|c|c|c|}
\hline \multirow{2}{*}{$\begin{array}{c}\text { Sector of } \\
\text { activity }\end{array}$} & \multicolumn{2}{|c|}{$\mathbf{1 9 6 1}$} & \multicolumn{2}{c|}{$\mathbf{2 0 1 1}$} \\
\cline { 2 - 5 } & Number & Share (\%) & Number & Share (\%) \\
\hline Primary & 90 & 88.2 & 7 & 20.6 \\
\hline Secondary & 1 & 1.0 & 4 & 14.7 \\
\hline Tertiary & 11 & 10.8 & 23 & 64.7 \\
\hline Total & 102 & 100.0 & 34 & 100.0 \\
\hline
\end{tabular}

Sources: SZS (1965.a), UMD (2011a)

At the time of the survey, the public sector had 4 full time and 3 part time employees including a teacher, a post office employee, who is also additionally working in the tourist office, a port authority employee, one full time and one half time garbage collector, all of whom were permanent residents. A doctor and a priest came to the island once a week. Private businesses including a construction business, a nautical tourism business, fishing, and rental business, a souvenir shop, a grocery shop, two boat taxi businesses, a café, and five restaurants employed 58 people ${ }^{7}$, of whom19 were employed full-time and 39 worked seasonally. All full time and only 4 seasonal workers in the private sector were permanent residents (Table 5).

Table 5

Entities by ownership and employees by the type of employment and residence on Ilovik in 2011

\begin{tabular}{|c|c|c|c|}
\hline & Public services & $\begin{array}{c}\text { Private } \\
\text { businesses }\end{array}$ & Total \\
\hline Number of entities & 7 & 12 & 19 \\
\hline Number of employees & 7 & 58 & 65 \\
\hline \multicolumn{4}{|l|}{ Employees by working time } \\
\hline Full time (year-round) & 4 & 19 & 23 \\
\hline Part time (year-round) & 3 & 0 & 3 \\
\hline Seasonal & 0 & 39 & 39 \\
\hline \multicolumn{4}{|l|}{ Employees by residence } \\
\hline Permanent residents & 5 & 20 & 25 \\
\hline Other & 2 & 38 & 40 \\
\hline
\end{tabular}

Source: UMD (2011b)

7 Since the survey one restaurant with one full-time and seven seasonal employees has been closed, so one permanent resident on Ilovik and seven people from outside lost their jobs. The construction business owner (permanent resident and a renter) closed his business and left, but the seasonal construction workers have remained working on the island. 
The majority of private businesses are operating only during the summer season. Only, the village grocery shop and one restaurant are open for public year round.

Restaurant businesses, the most important economic activity on the island, employed 29 persons (9 full-time and 20 seasonally) in 2011. The café and the nautical tourism each employed seven workers (the café - 1 full-time and 6 seasonal workers; the nautical tourism office - 3 full-time permanent residents and 4 seasonal workers). Two water taxi businesses employed one full time permanent resident each, the grocery shop three seasonal employees, and the souvenir shop one seasonal employee. The construction business had one full-time permanent resident employee and 5 seasonal workers. The fishing business employed three permanent residents full-time.

Views of the permanent resident towards the tourism industry, the most important economic factor in the development of the island, showed that the vast majority (71 percent) believed that tourism should increase, while others believed it should remain on the present level. The preferred way of growth is continued development of nautical tourism, followed by increase in long-term room and apartment rentals, and an increase in the number of daily excursions. Camping is viewed as the least desirable or completely unwanted type of tourism in the village. Still, all of the respondents in the survey would not object if a camp was placed on the island, away from the village. Permanent residents are not eager to have "newcomers" on the island, although a large number of building structures remain empty and decaying. A majority ( 58 percent)view potential new house owners or long term renters as the agents of change, 16 percent are unsure of their influence, and only a quarter do not believe the new "newcomers" would change the lifestyle on Ilovik.

Interestingly, similar views towards the tourism industry have been registered among dual residents, and interviewed homeowners who have their permanent residency elsewhere in the country or abroad. Two thirds believed tourism should increase, while others desired no change. Only one person viewed present level of tourist development as too high. The preferred growth in tourist industry is in nautical tourism, followed by increase in long-term room and apartment rentals, and daily excursions. Almost two thirds of vacation owners and dual residents believe new owners and renters would change the way of life on the island; one third do not view them as the agents of change.

\subsection{Accession to the European Union, and Government Involvement in Development}

Survey participants' views on the accession of Croatia to the EU, and its potential impact on the sustainable development of the island were similarly distributed among the age groups. Almost half of the heads of permanent resident households( 45 percent) were for the admission to the EU, a third against, while one fifth was undecided. Slightly stronger support to the accession of Croatia to the EU is observed 
among men and working age respondents, than among women and the elderly. More than a half ( 55 percent) of the participants expected significant changes (both positive and negative) upon admission into the EU, about a third did not expect significant changes, and the rest were not sure about the outcome, or did not answer the question (Table 6).

Among the 25 non-residents the views were slightly different. Ten were in favor, and ten were against the admission of Croatia to the EU, four were undecided, and only one did not answer. The support of accession to the EU is equally distributed among the age groups, while stronger support is observed among men than women (Table 7). More than half (13respondents)expected significant change after the accession, 10 did not expect any changes, and 2 did not know what to expect. Majority who is expecting significant changes are pessimistic, believing the situation will worsen (e. g. higher taxes and prices),but some were expecting more order after Croatia is admitted to the EU.

Table 6

Views of the permanent residents on the accession of Croatia into the European Union by sex and age, in 2011

\begin{tabular}{|c|c|c|c|c|c|}
\hline Age/Sex & For & Against & Undecided & $\begin{array}{c}\text { Did not } \\
\text { participate }\end{array}$ & Total \\
\hline $15-44$ & 1 & 0 & 1 & 0 & 2 \\
\hline $45-64$ & 7 & 5 & 2 & 1 & 15 \\
\hline $65+$ & 6 & 5 & 3 & 6 & 20 \\
\hline Male & 9 & 6 & 2 & 2 & 19 \\
\hline Female & 5 & 4 & 4 & 5 & 18 \\
\hline Total & 14 & 10 & 6 & 7 & 37 \\
\hline
\end{tabular}

Source: UMD (2011a)

Table 7

Views of the dual residents and vacation home owners on the accession of Croatia into the European Union by sex and age, in 2011

\begin{tabular}{|c|c|c|c|c|c|}
\hline Age/Sex & For & Against & Undecided & $\begin{array}{c}\text { Did not } \\
\text { participate }\end{array}$ & Total \\
\hline $15-44$ & 1 & 1 & 0 & 0 & 2 \\
\hline $45-64$ & 3 & 3 & 1 & 1 & 8 \\
\hline $65+$ & 6 & 6 & 3 & 0 & 15 \\
\hline Male & 9 & 6 & 2 & 1 & 18 \\
\hline Female & 1 & 4 & 2 & 0 & 7 \\
\hline Total & 10 & 10 & 4 & 1 & 25 \\
\hline
\end{tabular}

Source: UMD (2011.a) 
The expectation of the local community from all levels of the government involvement in the island's local business and development is divided. Half of the participants believe the government has not paid enough attention to their needs, a third judge government participation as sufficient, four are undecided, and two have not answered the question. When asked about their priorities for projects to be carried out with the government and its financial contribution, building marina was at the top of the list (6 respondents), followed by the water supply system (5), sewer system (3) and pier reconstruction (3) ${ }^{8}$. Only three respondents stated that all the projects, permits, or proposals submitted by the islanders to the government were successfully finished, and eight were not sure about the extent of the government involvement in the development of Ilovik.

When asked their preferences for the government engagement in providing better services on the island majority listed the initiatives (projects) already in the government development program for the island (e.g. pier reconstruction/delivered in May 2012), sewer and water system (in progress), road connecting from Mrtvaška on the island Lošinj (700 meters from Ilovik) to the city of Mali Lošinj (under construction) and minibus connection (in place since 2012). In addition, more money needed for the development, a need for more children on the island, better organized tourist board, etc. was on their list. They also expressed their dissatisfaction with the government (e.g. corruption, politicians). Only four people mentioned that the local community should be more engaged in the development of the island (e.g. better coordination between the island's local committee, and the county government, local community should press harder for government involvement), and only three respondents were satisfied with the present situation.

Although the non-residents do not have the same weight on decision making and negotiations with the county and regional government as the permanent residents do, they, as property owners, have very high stake in community development. Their expectation from all levels of the government involved in the island's development is equally divided as from the permanent residents. Almost half of the respondents believe the government has not paid enough attention to the island's needs and the third say involvement issufficient; others do not have an opinion about the extent of the government involvement in the development of the island. On the other hand, unlike permanent residents, they are less informed about the local community development proposals to be carried out by the government. Majority could not point out a single project that was proposed by the local community but not yet carried out by the government. Still, their priorities for Ilovik's development are equal to those of the permanent residents: construction of water and sewer system, solving transportation problems (e.g. enlargement of the main pier, connection of Ilovik with Mrtvaška on Mali Losinj), and increasing the number of young population by providing better job opportunities on the island.

8 Since the survey was carried out in June 2011, the pier was rebuilt to serve larger boats. 


\section{Discussion}

Population dynamics have a significant influence on sustainable development of small islands (United Nations Population Fund [UNFPA], 2011). The demographic imbalance of Ilovik is a result of long term out-migration and negative natural growth rate of the population.(Lajić, 2005). After reaching its peak in 1921, a steady population decrease has been experienced ever since. Initially, those who migrated out of Ilovik in search for work eased some population pressures on land as subsistence agricultural on the island could not sustain growing population. After the initial benefits, the negative effects of their absence and the absence of their future generations started to take effect. Long lasting emigration and out-migration, caused by agricultural density and other unfavorable economic factors, soon resulted in total depopulation of Ilovik and other small remote Croatian islands (Smoljanović, Smoljanović and Nejašmić, 1999; Magaš, Faričić and Lončarić, 2006:210-211; Faričić, 2012; Graovac, 2008:483-484; Klempić Bogadi and Podgorelec, 2011.). It prompted decrease in the birth rates and resulted in ageing population causing higher death rates, and consequently negative natural change. Beside the change in age composition, decrease in the birth rates was influenced by the lack of the cohorts in reproductive age (Lajić and Mišetić, 2006).

Already in 1961 the natural growth rate of the population of Ilovik continues to decline reaching higher number of deaths then live births. Since 1961 the natural decrease of Ilovik's population has been intensifying and it has had an increasing role in total depopulation. Therefore, the natural decrease since the 1961 is a result of persistently higher number of deaths then live births, as well as the continued decrease of women of fertile age.

Slowing down of depopulation in the 1980s and 1990s was a result of change in the direction of migration, although rather high negative natural change persisted. Positive net-migration in that period was connected to: (1) the exhaustion of the potential emigrant contingent (everyone that had wanted to leave the island, already left and only elderly people less inclined to migration stayed on the island), (2) development of tourism starting slowly from the 1980sincreasing employment opportunities, and (3) return migration flow, mainly retirees from overseas. Accelerated depopulation started in 2001-2011, when the island lost one fourth of its population as a result of negative net-migration. Once again younger adults and their children were leaving the island because of insufficient job market, or inadequate education for children', and insufficient return migration flow could not overturn negative net-migration (Šulc and Valjak, 2012:167-169). Instead, the older age composition in 2011 was a result of age selective out-migration and return retiree in-migration stream. Lack of women in fertile age, and disrupted age-sex composition domi-

9 There is one elementary school with one employed teacher on the island. At the time of the survey, there were 6 children of different age enrolled in the school. Besides, students in higher classes ( 5 to 8 ) are connected by internet to a school in Mali Lošinj where they take different subject courses (science, language,...). 
nated by elderly population negatively effects demographic resources and reduces prospects for demographic revitalization, jeopardizing sustainability of development on Ilovik and other small remote Croatian islands (Nejašmić, 1992:31; Graovac, 2008:494; Magaš and Faričić, 2002).

Dependency ratio, an indicator of a potential burden on the working-age population, is high on the island, with a prospect for further increase. Any natural increase of population becomes less likely in the future as the average population age increases, women in their reproductive age diminish, and the employment opportunities stagnate. It is questionable whether such negative present population dynamic, or even slight increase in the population numbers in the near future, could sustain forthcoming economic structure and employment requirements on the island and weather present socio-economic conditions could attract newcomers, other than retirees, to the island (Graovac, 2008). On the other hand, having in mind low job opportunities, lack of houses for sale, and resistance to rent, it is unlikely to expect younger newcomers, who would be able to influence population revitalization process, to arrive to the island.

Economic development of Ilovik is inseparably related to population changes. Favorable employment opportunities are generally an important factor in keeping the population in check and attracting newcomers. A lack of jobs and poor opportunities to earn a living are key push factors of out-migration and emigration. Changes in the number and composition of households are directly related to the demographic and general socio-economic transformation on the island. Over the past century, lack of jobs and poor opportunities to earn for living were key push factors of outmigration and emigration. Besides, these migrations significantly reduced population in the reproductive age, and played an important role in fast population ageing. In the late 1950s and 1960s, intensive deagrarization began, pushing people from the island and causing economic restructuring. In several decades, predominantly agricultural and fishing activities on the island have been replaced with tourism and dependent elderly population.

Lack of economic activities, social and physical infrastructure to support jobs that attract younger population and increase in-migration and natural increase, further limits the population and economic recovery of the island. Although population of Ilovik is generally better educated than Croatia, the population with the highest level of education on the island is elderly, returned migrants. Still, long-term tourists, and return migrants, bring with them the need for increase of living standard, which pushes for further economic development. Unfortunately, present population development cannot sustain such demands.

Majority of the people on Ilovik view the accession to the European Union as a new challenge. Whether they are for or against accession, they are worried it could bring new rules, and more problems, together with new real estate buyers and more tourists to the island. The villagers want to preserve tranquility of the environment and their lifestyle, but at the same time they are aiming for continues economic growths and infrastructure investments. The other interviewed owners, majority of 
who were residents on the island prior to emigration, had similar views. Although they are more prone to change, they are not eager to have "newcomers" who may change the lifestyle on the island. Homeowners who have never been residents on Ilovik, and are themselves considered as "newcomers," are cautious of change, but open to new challenges of the accession to the European Union.

The survey results indicate that the residents of Ilovik have limited knowledge and understanding about government involvement in revitalization and financing development of the island. Even less informed are the non-resident participants, who often are not aware of proposed programs and plans for government action. According to the information gathered from the survey, as well as the interviews with the local officials, it was evident that the small island had been getting a significant attention and financial help from the government to further develop the island's infrastructure and connection with the mainland in an effort to reduce the effects of depopulation and the island limited economic capacity. Work on most projects indicated to be essential for further progress of the island, have either already been in progress at the time of the interviews, or scheduled to start in the near future. Therefore, there is a dire need for better planning and coordination between the local community, private business development, non-resident stakeholders, and the infrastructure provisions by the government on the island.

\section{Conclusion}

The small island of Ilovik provides the compactness and isolation needed to fully analyze interrelationships among the population, its socio-economics status, its natural and built environment. It faces considerable vulnerability and sustainability challenges due to its aging population, economic dependability on tourism, low employment opportunities, and resistance to change by the local population. Nevertheless, the island unique characteristics make it desirable for future development.

Although population is no longer out-migrating in large numbers, and there are some tendencies of balance the population with in-migration retirees, natural growth rates is too low to offset a decline of the population on Ilovik. The aging population of the island's permanent population will have wide range implications on the future development. Economically, it is vulnerable to both internal change and external markets. Therefore, it is important to attract the type of tourism that would contribute to Ilovik's unique characteristics. Socially it has limited human resources and depends on in-migration for any positive change. While there is no doubt that permanent population on the island should have a major role in the future development of Ilovik, a large number of non-resident home owners have also high interest in balanced development of the island. They are equally interested in preserving Ilovik's traditional values and protection of natural resources, but less oppose to necessary changes leading to better services, stronger in-migration, vibrant housing market, and better economic development. Due to its marginalisation, Ilovik's insularity might impede a timely response for the needed resources and action. The consequences of inaction could be worse than at another less isolated location experiencing similar vulnerabilities. Therefore, it should be government priority to 
closely work with the local community and other stakeholders in preserving the small island's fragile socio-economic and natural environment.

The long term development perspectives on Ilovik are fragile and will depend on population recovery and further increase of employment opportunities. It is eminent to protect the traditional values of the Ilovik society and maintain the landscape of the island, whilst allowing for the balanced development of compatible activities, especially tourism. At this point the villagers are aware of theirs defenselessness, and are skeptical of getting sufficient help from the government to prevent undesirable investments on Ilovik. Still, delicate eco system and unique cultural heritage of the small island should be protected from excessive growth and change. The challenges of managing the vulnerabilities of Ilovik's culture and natural resources, and of achieving sustainability through such action, are enormous.

\section{Bibliography}

1. Bayle-Ottenheim, J.; Bedford, R.; Gonzalez, J. C.; Isamu, T.; Oliva Peńa, J. L.; Robinson, C.; Taufao, S. (2002). Further views on small-island carrying capacity. Coastal Practices for Sustainable Human Development Forum. Accessed $2^{\text {nd }}$ January 2013 (http://www.csiwisepractices.org/?read=452).

2. Buhalis, D. (1999). Tourism on the Greek islands: Issues of peripherality, competitiveness and development. International Journal of Tourism Research, 1 (5): 341-358.

3. Croatian Bureau of Statistics (1996). Popis stanovništva 1991.: Stanouništvo u zemlji i inozemstvu po naseljima, Dokumentacija 911. Zagreb: Croatian Bureau of statistics.

4. Croatian Bureau of Statistics (2003). Census 2001: Population aged 15 and over, by age, sex and level of educational attainment, by settlements (CD-ROM). Zagreb: Croatian Bureau of Statistics.

5. Croatian Bureau of Statistics (2005). Naselja i stanovništvo Republike Hrvatske 1857-2001 (CD-ROM). Zagreb: Croatian Bureau of Statistics.

6. Croatian Bureau of Statistics (2010). Rođeni i umrli po naseljima 1963. - 2010. (tablogrami). Zagreb: Croatian Bureau of Statistics.

7. Croatian Bureau of Statistics (2012). Census 2011: Population by age and sex, by settlements. Accessed 30 ${ }^{\text {th }}$ December 2012 (http://www.dzs.hr/default e.htm).

8. Deschenes, P. J. and Chertow, M. (2004). An island approach to industrial ecology: towards sustainability in the island context. Journal of Environmental Planning and Management, 47 (2): 201-217.

9. Duplančić Leder, T.; Ujević, T. and Čala, M. (2004). Coastline lengths and areas of islands in the Croatian part of the Adriatic Sea determined from the topographic maps at the scale of $1: 25$ 000. Geoadria, 9 (1): 5-32.

10. Faričić, J. (2012). Geografija sjeverno dalmatinskih otoka. Zagreb: Školska knjiga.

11. Faričić, J. i Mikuličić, D. (2010). Turizam - jezgra suvemene aktivnosti na Istu i Škardi, u: Faričić Josip (ed.). Otoci Ist i Škarda. Zadar: Sveučilište u Zadru, Zavod za prostorno uređenje Zadarske županije, Matica hrvatska - Ogranak u Zadar i Hrvatsko geografsko društvo - Zadar, 751-766. 
12. Faričić, J.; Graovac, V. and Čuka, A. (2010). Croatian Small Islands - Residential and/or Leisure Area. Geoadria, 15 (1): 145-185.

13. Graovac, V. (2008). Depopulacija otoka Rave, in: Faričić Josip (ed.). Otok Rava. Zadar: Sveučilište u Zadru, Zadar za prirodne znanosti HAZU, 479-496.

14. Klemenčić, M. (1990). Postupak vrednovanja dobnog sastava stanovništva. Radovi, 25: 73-80.

15. Klempić Bogadi, S. and Podgorelec, S. (2011).Socio-geographic changes in small island communities - the example of the island of Zlarin. Geoadria, 16 (1): 189209.

16. Lajić, I. (2005). Present Demographic Situation on the Island of Ilovik, in: Črnjar Mladen and Šišić Sonja (ed.). Analiza razvojnih potencijala otoka. Mecunarodna radionica. Zbornik radova. Rijeka: UNESCO Venice Office, Primorsko-goranska županija, Županijski zavod za održivi razvoj i prostorno planiranje, IUAV di Venezia, 58-63.

17. Lajić, I. (2006). Kvarnerski otoci - demografski razvoji povijesne mijene. Zagreb: Institut za migracije i narodnosti.

18. Lajić, I. i Mišetić, R. (2006). Otočni logaritam. Aktualno stanje i suvremeni demografski procesi na jadranskim otocima. Zagreb: Institut za migracije i narodnosti, Ministarstvo mora, turizma, prometa i razvitka.

19. Lončar, J. and Maradin, M. (2009). Environmental challenges for sustainable development in the Croatian North Adriatic Littoral Region. Dela, 31: 159-173.

20. Mackelworth, P. C. and Carić, H. (2010). Gatekeepers of island communities: exploring the pillars of sustainable development. Environment Development and Sustainability, 12(4): 463-480.

21. Magaš, D. (2008). Geografske posebnosti razvitka malih hrvatskih otoka, u: Faričić Josip (ed.). Otok Rava. Zadar: Sveučilište u Zadru, Zadar za prirodne znanosti HAZU, 19-40.

22. Magaš, D. and Faričić, J. (2002).Problemi suvremene socio-geografske preobrazbe otoka Oliba. Geoadria, 7 (2): 35-62.

23. Magaš, D.; Brkić Vejmelka, J. and Faričić, J. (2000). New Geographic Concepts of Developing Tourism on the Small Croatian Islands. Conditions of the Foreign Tourism Development in Central and Eastern Europe, 6, 239-270.

24. Magaš, D.; Faričić, J. i Lončarić, R. (2005). Osnovni geografski čimbenici suvremen preobrazbe Ilovika. Geoadria, 10 (1): 21-51.

25. Magaš, D.; Faričić, J. and Lončarić, R. (2006). Geographical basis of socio-economic revitalization of Unijeisland, Croatia. Geoadria, 11 (2): 173-239.

26. Nejašmić, I. (1992). Promjene u dobno-spolnom sastavu stanovništva istočno jadranskog otočja. Acta geographica Croatica, 27: 15-34.

27. Nejašmić, I. (2005). Demogeografija: stanouništvo u prostornim odnosima i procesima. Zagreb: Školskaknjiga.

28. Nejašmić, I. and Mišetić, R. (2006). Depopulation of Vis island, Croatia. Geoadria, 11 (2): 283-309.

29. Nunkoo, R.; Gursoy, D. and Juwaheer, T. D. (2010). Island residents' identities and their support for tourism: an integration of two theories. Journal of Sustainable Tourism, 18 (5): 675-693.

30. Savezni zavod za statistiku (1965a). Popis stanovništva 1961. - Knjiga XIV: aktivnost $i$ delatnost, rezultati za naselja. Beograd: Savezni zavod za statistiku. 
31. Savezni zavod za statistiku (1965b). Popis stanovništva 1961. - Knjiga XI: pol i starost, rezultati za naselja. Beograd: Savezni zavod za statistiku.

32. Savezni zavod za statistiku (1965c). Popis stanovništva 1961. - Knjiga XIII: školska sprema i pismenost, rezultati za naselja. Beograd: Savezni zavod za statistiku.

33. Savezni zavod za statistiku (1965d). Popis stanovništva 1961. - Knjiga XVI: veličina $i$ izvori priboda domaćinstava, rezultati za naselja. Beograd: Savezni zavod za statistiku.

34. Smoljanović, M.; Smoljanović, A. i Nejašmić, I. (1999). Stanovništvo brvatskih otoka. Split: Zavod za javno zdravstvo Splitsko-dalmatinske županije.

35. Starc, Nenad (2001). Managing island development: the Croatian case. Sociologija sela, 39 (1-4) (151-154): 15-36.

36. State Geodetic Administration (2005). Središnji registar prostornih jedinica RH. Zagreb: State Geodetic Administration.

37. Šulc, I. i Valjak, V. (2012). Zaštićena područja u funkciji održivog razvoja hrvatskog otočja - primjer otoka Mljeta. Hrvatski geografski glasnik, 74 (1): 161-185.

38. United Nations Population Fund (2011). Population Matters for Sustainable Development. Interagency Consultation on Population and Sustainable Development. New York: United Nations Population Fund.

39. University of Maryland (2011a). Population Survey on Ilovik in June 2011.

40. University of Maryland (2011b). Business Owners Survey on Ilovik in June 2011.

41. Wertheimer-Baletić, A. (1982). Demografija. Stanouništvo i ekonomski razvitak. Zagreb: Informator.

42. World Commission on Environment and Development (1987). Report of the World Commission on Environment and Development: Our Common Future. UN document A/42/427. Accessed $2^{\text {nd }}$ January 2013 (http://www.un-documents. net/wced-ocf.htm). 
Izvorni znanstveni rad

Ivan $\check{S} u l c$

Prirodoslovno-matematički fakultet, Geografski odsjek, Sveučilište u Zagrebu, Hrvatska

e-mail: isulc@geog.pmf.hr

\section{Mila Zlatić}

Sveučilište Maryland, Geografski odsjek, Maryland, SAD

e-mail:mila.zlatic@umd.edu

\section{Demografski izazov održivosti malih jadranskih otoka: slučaj Ilovika u Hrvatskoj}

\section{Sažetak}

Tradicionalni način života na malim otocima ugrožen je širom svijeta. Ovaj rad pruža uvid u razvoj malog hrvatskog otoka Ilovika u Jadranskom moru zahvaćenog negativnim demografskim trendovima koji utječu na društveno-gospodarske i okolišne procese, te predstavljaju poseban izazov za planiranje i postizanje održivog razvoja otoka. Sredinom lipnja 2011. g., u razdoblju od dva tjedna, provedeno je istraživanje sa stalnim stanovništvom, povremenim stanovništvom i vlasnicima vikendica (ili kuća za odmor) Ilovika koje je obuhvatilo njihov društveno-gospodarski položaj, okoliš, percepciju turizma, utjecaj vlasti na društveno-gospodarske promjene te utjecaj Europske unije na budući razvoj. U radu su analizirani rezultati istraživanja i uspoređeni su sa službenim podacima iz prijašnjih popisa stanovništva i vitalne statistike. Glavni cilj rada bio je istražiti sadašnji stupanj održivosti Ilovika i omogućiti razumijevanje njegove slabije razvojne perspektive koja će ovisiti o demografskoj revitalizaciji i poboljšanju mogućnosti zapošljavanja, uzimajući pritom u obzir osjetljiv ekosustav i jedinstvenu kulturnu baštinu malog otoka.

Ključne riječi: depopulacija, održivi razvoj, mali otoci, Ilovik, jadranski otoci, Hrvatska. 